\title{
Phenotypic and genotypic distribution of nodules on soybean root system inoculated with Bradyrhizobium japonicum strain G49
}

\author{
N Burias *, C Planchon, MH Paul \\ Laboratoire d'Amélioration des Plantes (Institut National Polytechnique), Ecole Nationale Supérieure Agronomique, \\ 145, Avenue de Muret, F-31 076 Toulouse Cedex, France
}

(Received 17 January 1989; accepted 6 October 1989)

\begin{abstract}
Summary - The nodulating and dinitrogen fixating abilities of Bradyrhizobium japonicum strain G49 were analyzed for 5 soybean genotypes grown hydroponically under various conditions of nitrate supply. The dinitrogen symbiotic fixation determined at stage $\mathrm{R} 5$ varied widely in relation to the host genotypes and environmental conditions. The genotypic effect on the distribution of the nodules on the root system is more clearcut. Some cultivars are unable to form nodules on their secondary roots or in the lower part of their root system. The absence of nitrates in the medium modified only moderately this distribution to the advantage of secondary roots and of the upper part of the root system where nodules appeared early. Thus, preferentially or occasionally infectible and non-infectible areas can be defined for the root system of each host genotype.
\end{abstract}

soybean / Bradyrhizobium japonicum / $\mathrm{N}_{2}$ fixation / nodule distribution

Résumé - Distribution phénotypique et génotypique des nodules sur le système racinaire du soja avec la souche de Bradyrhizobium japonicum G49. Les capacités de nodulation et de fixation de l'azote de la souche G49 de Bradyrhizobium japonicum sont analysées pour 5 génotypes de soja, cultivés sur solutions nutritives dans diverses conditions de fourniture de nitrate. La fixation symbiotique de l'azote, mesurée au stade R5, varie dans de grandes proportions, en relation avec les génotypes et les conditions du milieu racinaire (tableau l). II existe un effet génotypique très net sur la répartition des nodules. Certaines variétés présentent une inaptitude à former des nodules sur les racines secondaires ou sur les parties inférieures du système racinaire (fig 1). La présence de nitrate dans le milieu racinaire modifie de façon limitée cette répartition en favorisant d'une part la nodulation sur la racine principale, et d'autre part sur les zones inférieures des racines (tableau II). II peut être ainsi défini pour chaque génotype des régions racinaires infectibles préférentielles ou occasionnelles et des régions racinaires non infectibles.

soja / Bradyrhizobium japonicum / fixation symbiotique d'azote / distribution nodulaire

\section{INTRODUCTION}

Soybean seed yield is highly dependent on the amount of nitrogen in the seed originating from symbiotic fixation (Nelson et al, 1984; Ronis et al, 1985): $N_{2}$ fixation efficiency seems a good criterion for the improvement of soybean productivity since the most economical way to provide additional nitrogen is through a more effective $\mathrm{N}_{2}$ fixation system.

Little research has concerned the influence of the host genotype on $\mathrm{N}_{2}$ fixation efficiency and on nodule formation and development, but variability in nodulation effectiveness and $\mathrm{N}_{2}$ fixation efficiency in the soybeanBradyrhizobium japonicum symbiosis has been observed for different combinations of these symbionts. Some genotypes in the presence of specific strains or serogroups of $B$ japonicum display an ineffective nodulation characterized by the occurrence of cortical proliferation where $\mathrm{N}_{2}$ fixation is deficient. The dominant gene Rij2 (Caldwell, 1966) borne by the plant restricts nodulation with all the available USDA 122 strains and serogroup $\mathrm{C} 1$. Another gene, Rj3

*orrespondence and reprints 
(Vest, 1970); is known to limit the plant ability to nodulate with bacterial strain USDA 33. The action of gene Rj4 (Vest and Caldwell, 1972) concerns strain USDA 61 . The macro-and the micro-symbiont must therefore be highly compatible to form an efficient symbiosis. Devine and Breithaupt (1980) have suggested that the use of the compatibility responses by the soybean breeder should allow the host specification towards genetically improved bacterial strains to be controlled. Specific soybean genotype-Bradyrhizobium japonicum strain combinations which might enhance soybean yields through more effective nodulation and biological $\mathrm{N}_{2}$ fixation have been identified (Kvien et al, 1981). Symbiotic $\mathrm{N}_{2}$ fixation depends markedly on the environmental conditions and the investigation of the mechanisms of initiation and regulation of nodulation requires the growth of the host plant under strictly controlled conditions. Plastic growth pouches (Weaver and Frederick, 1972) satisfy this requirement, but the nodulation of pouchgrown soybean is monitored on a restricted portion of the root system of the seedlings. Bhuvaneswari et al (1980) developed a convenient method for studying the location and development of infectible cells on legume roots; in soybean, these cells appear to be located just above the zone of root elongation and just below the position of the smallest emergent root hairs at any given time. The infectibility of host cells is a transient property that appears and then is lost within a few hours. Later, Pierce and Bauer (1983) reported the existence of a rapid regulatory response that inhibits nodulation of distal portions of the primary root following inoculation of seedlings with Bradyrhizobium japonicum. The plant controls the extent of cell division (and thus nodule development) in the root cortex and its associated pericycle by limiting infectivity to certain regions on the root, restricting the infectability of root hairs within these regions and finally regulating the degree of general cortical cell division (Pierce and Bauer, 1983; Mathews, 1987). In fact, regulation of nodulation on the primary root thus appears to be variable and depend on strain-cultivar interactions (Heron and Pueppke, 1987).

The assumption of the involvement of a glycoprotein (lectin) in the recognition mechanism between symbionts was put forward first by Bohlool and Schmidt (1974), then by Dazzo and Hubbell (1975) and Bhuvaneswari et al (1977). This lectin ( $\mathrm{mw}=120 \mathrm{kd}$ ) occurs in most soybean cultivars in seeds, leaves, stems and roots, and ensures the polar binding of the bacteria onto the root absorbing hairs (Pull et al, 1978). Besides, only a small fraction of the total infections generated by the rhizobial strains results in the development of visible nodules on the roots (Calvert et al, 1984). Nodule morphogenesis is also controlled by the plant: various plant-derived compounds have been identified in root exudates that can either activate or antagonize nod gene expression (Firmin et al, 1986). In soybean, isoflavones (daidzein, genistein and coumestrol) have been isolated and shown to induce bacterial nod genes rapidly (Redmond et al, 1986).

Several other physiological and environmental factors, such as nitrate levels, also affect nodulation. Nitrate inhibition of nodulation (root hair infection, nodule growth and development) and $\mathrm{N}_{2}$ fixation has been investigated by Harper and Cooper (1971), Gibson and Jordan (1983), Gibson and Harper (1985) and Drevon et al (1988). However, nitrate itself does not seem likely to be the active inducer of infectioninhibiting responses in the host (Malik et al, 1987).

The aim of the investigations reported here was to analyze the distribution of the nodules on the root system in relation to the host genotype and the presence for various durations of nitrate which could modify the nodule colonization rate. The measurement of symbiotic dinitrogen fixation using the acetylene reduction assay allowed nodule efficiency to be assessed.

\section{MATERIALS AND METHODS}

\section{Plant material and growth conditions}

Five soybean (Glycine max (L) Merr) cultivars of differing geographical origins and earliness were used:

- Fiskeby V (Sweden)

- Maple Arrow (Canada)

- KZ 42 (Eastern Europe)

- Jiling 14 (China)

- Kingsoy (USA)

Maturity group : 000

Maturity group : 00

Maturity group : 00

Maturity group : 1

Maturity group : II

Three series of experiments were carried out in phytotronic chambers with a $14 \mathrm{~h}$ daily photoperiod at $270 \mu \mathrm{E} \mathrm{m}^{-2} \mathrm{~s}^{-1}$ (PAR) irradiance and $25 / 20^{\circ} \mathrm{C}$ light/dark temperatures. In order to observe the initiation and growth of nodules without destroying the plants, these were grown under soilless culture conditions, in continuously aerated (air flow rate: $4 \mathrm{l} \cdot \mathrm{min}^{-1}$ ) $20 \mathrm{~L}$ $20 \mathrm{~cm}$ deep tanks. After a preliminary study, the nutrient solution IRAT (1) enriched in magnesium

(1) $10^{-2} \mathrm{~g} / \mathrm{l}: \mathrm{KH}_{2} \mathrm{PO}_{4}$ 13.6; $\mathrm{K}_{2} \mathrm{HPO}_{4} 17.4 ; \mathrm{K}_{2} \mathrm{SO}_{4} 8.7 ; \mathrm{CaCl}_{2}$, $2 \mathrm{H}_{2} \mathrm{O} 14.7 ; \mathrm{MgSO}_{4}, 7 \mathrm{H}_{2} \mathrm{O} 61.6 ; 10^{-4} \mathrm{~g} / \mathrm{l}: \mathrm{MnSO}_{4}, \mathrm{H}_{2} \mathrm{O} 12.3$; $\mathrm{ZnSO}_{4}, 7 \mathrm{H}_{2} \mathrm{O}$ 8.82; $\mathrm{H}_{3} \mathrm{BO}_{3}$ 5.64; $\mathrm{CuSO}_{4}, 5 \mathrm{H}_{2} \mathrm{O}$ 1.36; $\left(\mathrm{NH}_{4}\right)_{6}$ $\mathrm{Mo}_{7} \mathrm{O}_{24}, 4 \mathrm{H}_{2} \mathrm{O} 1 ; \mathrm{CoSO}_{4}, 7 \mathrm{H}_{2} \mathrm{O} 0.46 ; \mathrm{FeSO}_{4}, 7 \mathrm{H}_{2} \mathrm{O} 747$; pH 5.8. 
supple-mented with a variable rate of nitrate as $\mathrm{Ca}\left(\mathrm{NO}_{3}\right)_{2}, 4 \mathrm{H}_{2} \mathrm{O}$ was used in every case:

- first series of experiments (number 1): plants grown in the absence of nitrate;

- second series of experiments (number 2): plants grown in the presence of nitrate $\left(\left[\mathrm{NO}_{3}^{-}\right]=8 \mathrm{mM}\right)$ until V2 stage, for 2 weeks only;

- third series of experiments (number 3): plants grown in the presence of variable amounts of nitrate as follows:

- first week (stage $\mathrm{VC}$ ): $\left[\mathrm{NO}_{3}^{-}\right]=6.4 \mathrm{mM}$,

- second week (stage $V_{1}-V^{\prime} 1$ ): $\left[\mathrm{NO}_{3}^{-}\right]=3.2 \mathrm{mM}$,

- third and fourth weeks (until stage $\mathrm{V} 4$ ): $\left[\mathrm{NO}_{3}^{-}\right]$ $=0.8 \mathrm{mM}$. The nitrate supply was then discontinued.

The stability of the nitrate content of the solution was checked daily by means of UV spectrophotometric determinations at $210 \mathrm{~nm}$ (Cawse, 1967).

The experimental design was a randomized complete block with 6 replications of 5 plants. A double inoculation was made: on the seed $\left(10^{6}\right.$ bacteria per seed) and in the hydroponic solution $\left(10^{6}\right.$ bacteria per liter) with G49 strain from commercial inoculum (LIPHA, Lyon, France).

\section{Parameters investigated}

The following parameters were analyzed 3 days per week during plant development:

- appearance of the first nodules;

- number and size of nodules (nodular volume):

- distribution of the nodules on the whole root system.

Symbiotic $\mathrm{N}_{2}$ fixation was determined by measuring the acetylene reduction activity (ARA) of the root system by the in situ method of Balandreau and Dommergues (1971). The root system of the whole plant was introduced into $580 \mathrm{ml}$ plasma bottles with $100 \mathrm{ml}$ of nitrogen-free nutrient solution; a Terostat 9010 (Teroson) gasket ensured air-tightness at the level of the collar. Forty-eight ml of air comprising $10 \%$ of the total gas volume was replaced with acetylene using a $50 \mathrm{ml}$ sterile hypodermic syringe. The bottles were placed under the initial growth conditions of the plant for one hour. Ethylene production is known to be linear throughout this period (Schweitzer and Harper, 1980 ) and the linearity was checked by gas sampling at various time intervals ( $30 \mathrm{~min}, 45 \mathrm{~min}, 1 \mathrm{~h}$ ) and a $5 \mathrm{ml}$ gas sample was then taken and analyzed by solid-gas chromatography with injection of $1 \mathrm{ml}$ (Intersmat IGC 120 FB chromatograph with a flame ionization detector and a stainless steel column filled with 60-80 mesh Porapak T).

\section{RESULTS}

\section{Variability of nodulation and symbiotic nitrogen fixation characteristics}

The host genotype and the root medium (absence or presence of nitrate in the solution for various durations) brought about marked variations in the ability of the plants to form and develop nodules, as expressed by the appearance of the first nodules and the nodular volume value at stage R5 (table I). Moreover, the $\mathrm{N}_{2}$

Table I. Appearance of the first nodules (stage of development ${ }^{* *}$ ), number of nodules, nodular volume $\left(\mathrm{mm}^{3}\right)$ and $\mathrm{N}_{2}$ fixation activity (ARA: $\mu \mathrm{mol} \mathrm{C}_{2} \mathrm{H}_{4}$ per $\mathrm{h}$ per plant at $\mathrm{R} 5 \mathrm{stage}$ ). ${ }^{*} 1,\left[\mathrm{NO}_{3}^{-}\right.$]: $0 \mathrm{mM} ; 2,\left[\mathrm{NO}_{3}^{-}\right]: 8 \mathrm{mM}$ until $\mathrm{V} 2$ stage; 3 , $\left[\mathrm{NO}_{3}^{-}\right]: 6.4 \mathrm{mM}$ until VC stage, $3.2 \mathrm{mM}$ until V'1 stage, $0.8 \mathrm{mM}$ until V4 stage; ** Fehr and Caviness, 1977.

\begin{tabular}{|c|c|c|c|c|c|}
\hline Genotypes & $\begin{array}{c}\text { Series of } \\
\text { experiments * }\end{array}$ & $\begin{array}{l}\text { Appearence of the } \\
\text { first nodules }\end{array}$ & $\begin{array}{l}\text { No of } \\
\text { nodules }\end{array}$ & $\begin{array}{l}\text { Nodular } \\
\text { volume }\end{array}$ & $\begin{array}{l}\text { Fixation } \\
\text { activity }\end{array}$ \\
\hline Maple Arrow & $\begin{array}{l}1 \\
2 \\
3\end{array}$ & $\begin{array}{l}\text { VE } \\
\text { V1 } \\
\text { VC }\end{array}$ & $\begin{array}{l}48 d \\
51 d \\
64 f\end{array}$ & $\begin{array}{r}103 \mathrm{c} \\
1000 \mathrm{i} \\
99 \mathrm{c}\end{array}$ & $\begin{array}{l}2.0 \mathrm{~g} \\
0.5 \mathrm{ab} \\
1.3 \mathrm{e}\end{array}$ \\
\hline$K Z 42$ & $\begin{array}{l}1 \\
2 \\
3\end{array}$ & $\begin{array}{l}\text { VC } \\
\text { V2 } \\
\text { V1 }\end{array}$ & $\begin{array}{l}10 \mathrm{a} \\
28 \mathrm{~b} \\
57 \mathrm{e}\end{array}$ & $\begin{array}{l}401 \mathrm{f} \\
307 \mathrm{e} \\
820 \mathrm{~h}\end{array}$ & $\begin{array}{l}2.1 \mathrm{~g} \\
0.4 \mathrm{a} \\
1.8 \mathrm{f}\end{array}$ \\
\hline Kingsoy & $\begin{array}{l}1 \\
2 \\
3\end{array}$ & $\begin{array}{l}\text { VC } \\
\text { V2 } \\
\text { V2 }\end{array}$ & $\begin{array}{l}20 b \\
23 b \\
47 d\end{array}$ & $\begin{array}{r}95 \mathrm{c} \\
484 \mathrm{~g} \\
64 \mathrm{~b}\end{array}$ & $\begin{array}{l}0.8 \mathrm{c} \\
0.3 \mathrm{a} \\
0.8 \mathrm{c}\end{array}$ \\
\hline Fiskeby V & $\begin{array}{l}1 \\
2 \\
3\end{array}$ & $\begin{array}{l}V C \\
V_{1} \\
V_{1}\end{array}$ & $\begin{array}{l}25 \mathrm{~b} \\
16 \mathrm{ab} \\
17 \mathrm{ab}\end{array}$ & $\begin{array}{r}96 \mathrm{c} \\
164 \mathrm{~d} \\
8 \mathrm{a}\end{array}$ & $\begin{array}{l}1,1 \mathrm{~d} \\
0.4 \mathrm{a} \\
0.5 \mathrm{ab}\end{array}$ \\
\hline Jiling 14 & $\begin{array}{l}1 \\
2 \\
3\end{array}$ & $\begin{array}{l}\text { VC } \\
\text { V2 } \\
\text { V2 }\end{array}$ & $\begin{array}{l}14 a \\
10 a \\
40 c\end{array}$ & $\begin{array}{r}94 c \\
120 c \\
16 a\end{array}$ & $\begin{array}{l}0.6 \mathrm{~b} \\
0.4 \mathrm{a} \\
0.6 \mathrm{~b}\end{array}$ \\
\hline \multicolumn{3}{|c|}{$\begin{array}{l}\text { Little significant difference } \\
\text { LSD }(0.05)\end{array}$} & 5 & 20 & 0.1 \\
\hline
\end{tabular}


fixation activities also varied, depending on the cultivar and on the amount of nitrate present in the growth medium. However, these differences in $\mathrm{N}_{2}$ fixation activity do not appear to be related to nodule volumes. In the second series of experiments, the early discontinuation of the nitrate supply resulted in a noticeable nodule development on plants (particularly the cultivar Maple Arrow) that were growing actively as a result of the initial nitrate rate. In every case, the nitrogenase activity was lower in the presence of nitrate.

\section{Genotypic and phenotypic characteristics of the nodule distribution on the root system}

The distribution of the nodules appears as a genotypic characteristic that is little influenced by the medium. Thus, some genotypes (table II) are unable to form and develop nodules:

- in the lower zone of the root system (Maple Arrow, Fiskeby),

- or on the secondary roots (KZ 42).

Among the 5 cultivars investigated, only Kingsoy and Jiling 14 displayed nodulation over the whole root system, particularly in depth. The absence of nitrate in the growth medium promoted the early appearance of nodules (table I) which were then distributed preferentially in the upper zone of the root system as well as on the secondary roots (table II).

Thus, each of these host genotypes could be characterized by a nodule profile with preferential or occasional zones of nodulation and with regions where nodules were systematically absent (figure 1). There were no significant differences in the depth $(47 \pm 3 \mathrm{~cm})$ of the root system between the various cultivars.

\section{DISCUSSION - CONCLUSION}

Symbiotic nitrogen fixation in soybean depends on the ability of the plant to nodulate and on the ability of the nodules to reduce atmospheric nitrogen. Although there is no relationship between the number of nodules and the $\mathrm{N}_{2}$ fixation activity, a minimum number of nodules is required. The nodule mass, the acetylene reduction activity and an early nodulation can be considered as good criteria for the selection

Table II. Distribution of the nodules on the root system (\% nodular volume). ${ }^{*}$ See table I.

\begin{tabular}{|c|c|c|c|c|c|c|c|c|c|c|c|}
\hline \multirow{2}{*}{$\begin{array}{l}\text { Genotypes and } \\
\text { series of experiments * }\end{array}$} & \multicolumn{3}{|c|}{ Whole root system } & \multicolumn{3}{|c|}{ Main root } & \multirow[t]{2}{*}{ Total } & \multicolumn{3}{|c|}{ Secondary root system } & \multirow[t]{2}{*}{ Total } \\
\hline & $\begin{array}{l}\text { Lower } \\
\text { part }\end{array}$ & $\begin{array}{l}\text { Median } \\
\text { part }\end{array}$ & $\begin{array}{l}\text { Upper } \\
\text { part }\end{array}$ & $\begin{array}{c}\text { Lower } \\
\text { part }\end{array}$ & $\begin{array}{l}\text { Median } \\
\text { part }\end{array}$ & $\begin{array}{l}\text { Upper } \\
\text { part }\end{array}$ & & $\begin{array}{l}\text { Lower } \\
\text { part }\end{array}$ & $\begin{array}{l}\text { Median } \\
\text { part }\end{array}$ & $\begin{array}{l}\text { Upper } \\
\text { part }\end{array}$ & \\
\hline \multicolumn{12}{|l|}{ Maple Arrow } \\
\hline 1 & 1.8 & 14.2 & 84 & 1.8 & 9.0 & 36.4 & 47.2 & 0 & 5.2 & 47.6 & 52.8 \\
\hline 2 & 0 & 26 & 74 & 0 & 12 & 40 & 52 & 0 & 14 & 34 & 48 \\
\hline 3 & 0 & 35.5 & 64.5 & 0 & 26 & 46 & 72 & 0 & 9.5 & 18.5 & 28 \\
\hline \multicolumn{12}{|l|}{$K Z 42$} \\
\hline 1 & 0 & 2.6 & 97.4 & 0 & 2.6 & 96.1 & 98.7 & 0 & 0 & 1.3 & 1.3 \\
\hline 2 & 8 & 9 & 83 & 8 & 9 & 82 & 99 & 0 & 0 & 1 & 1 \\
\hline 3 & 2 & 29 & 69 & 2 & 29 & 67 & 98 & 0 & 0 & 2 & 2 \\
\hline \multicolumn{12}{|l|}{ Kingsoy } \\
\hline 1 & 18.7 & 11.4 & 69.9 & 18.7 & 0.2 & 45.7 & 64.6 & 0 & 11.2 & 24.2 & 35.4 \\
\hline 2 & 95.9 & 3.3 & 0.8 & 64.5 & 3 & 0.5 & 68 & 31.4 & 0.3 & 0.3 & 32 \\
\hline 3 & 37 & 7 & 56 & 34.7 & 5.3 & 49 & 89 & 2.3 & 1.7 & 7 & 11 \\
\hline \multicolumn{12}{|l|}{ Fiskeby V } \\
\hline 1 & 1.3 & 26.5 & 72.2 & 1.3 & 11 & 33.6 & 45.9 & 0 & 15.5 & 38.6 & 54.1 \\
\hline 2 & 1.1 & 30 & 68.9 & 1.1 & 30 & 18.4 & 49.5 & 0 & 0 & 50.5 & 50.5 \\
\hline 3 & 0 & 31.4 & 68.6 & 0 & 31.4 & 60 & 91.4 & 0 & 0 & 8.6 & 8.6 \\
\hline \multicolumn{12}{|l|}{ Jiling 14} \\
\hline 1 & 15.1 & 6.3 & 78.6 & 15.1 & 6.3 & 58.8 & 80.2 & 0 & 0 & 19.8 & 19.8 \\
\hline 2 & 13 & 28 & 59 & 13 & 28 & 40 & 81 & 0 & 0 & 19 & 19 \\
\hline 3 & 14 & 53 & 33 & 14 & 53 & 25 & 92 & 0 & 0 & 8 & 8 \\
\hline LSD (0.05) & 1.5 & 3 & 3.5 & 2 & 3 & 4 & 4 & 1 & 1.5 & 3 & 3.5 \\
\hline
\end{tabular}




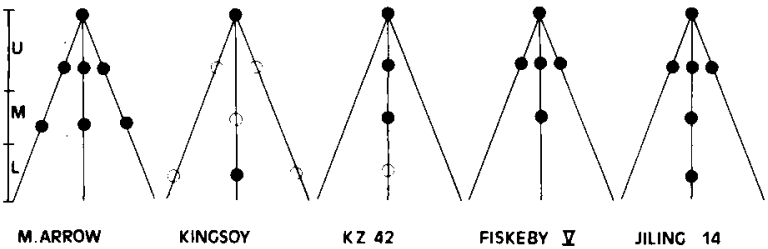

Fig 1. Nodulation profiles of the different genotypes; : preferential zones of nodulation; $O$ : occasional zones of nodulation; $U$ : upper part of the root system; $M$ : median part of the root system; $L$ : lower part of the root system.

of the best host genotype-Bradyrhizobium japonicum strain couples (Hardarson et al, 1984).

The occurrence and the distribution of the nodules are controlled by the host legume. Caldwell and Vest (1968) gave evidence for specific interactions between soybean genotypes and $B$ japonicum serogroups in nodule formation. The number of nodules forming on a root after Rhizobium infection is influenced by a plant process called autoregulation (Pierce and Bauer, 1983). Infections mostly concern a distinct region of the legume root just behind the root tip. This region is characterized by the presence of newly emerging root hairs, which are susceptible to curling and invasion via an infection thread.

Although there is a wide phenotypic variability for symbiotic nitrogen fixation and for the nodule volume developed, the distribution of the nodules over the root system appears as a genotypic constant.

The data reported here show that the colonization of the root system by the bacteria proceeds, depending on the host genotype, preferentially on the main root or on the secondary roots, or in the upper, median or lower zones of the root system. All the cultivars grown hydroponically do not have the ability to nodulate in depth and/or on their secondary roots. The same results have been obtained with plants developed in pots containing a sand-soil-peat mixture (unpublished data) and will be checked under field conditions later on. These differences result in nodulation profiles that are characteristic of the cultivars and can originate from a control by the plant at the time of infection by the rhizobial strain and/or during nodule formation from the infection points.

These results confirm that all soybean cultivars do not possess the same ability to autoregulate. Even within a species with a small genetic base such as soybean, there is some diversity in the ability to regulate the nodulation response. Regulation of flavonoids synthesis in the vicinity of developing infection threads or by translocation from other plant parts could be a mechanism by which legumes act on nodulation. The inhibitory activity of the nitrate level may be slightly modulated through effects on the fundamental autoregulation.

The differences in nodule profiles observed on the 5 cultivars investigated can influence the symbiotic response during climatic stresses. The position of the nodules on the root system can influence the development and the yield since the nodules that are close to the soil surface are very sensitive to variations in the environmental conditions. The sensitivity of the nodules to dehydration (Sinclair and Weisz, 1985; Obaton et al, 1988) during periods of prolonged drought argues for a development of the nodules in the lower part of the root system (Kingsoy type). When there is a plentiful water supply, the high number of nodules (Maple Arrow type) may ensure effective symbiosis over the whole of the development cycle. Moreover, the nodular function is also very dependent on the temperature of the rooting medium (Denison and Sinclair, 1985). High $\left(>35^{\circ} \mathrm{C}\right.$ ) as well as low $\left(<20^{\circ}\right)$ temperatures can affect soybean $\mathrm{N}_{2}$ fixation markedly and the temperature gradients occuring in the soil during various periods can be favourable to some genotypes in relation to the depth of their nodules.

It can thus be assumed that the improvement of nitrogen nutrition, and therefore of soybean yield, requires a selection of the cultivars that are the best adapted, through their nodular characteristics, to given environmental conditions.

\section{ACKNOWLEDGMENTS}

These investigations received financial support from French Soybean Breeders (Groupement d'Intérêt Economique (GIE) des Sélectionneurs de Soja, Paris). The authors thank Dr Obaton for critical reading of the manuscript. This paper is part of a PhD dissertation submitted by the first author to the Institut National Polytechnique of Toulouse.

\section{REFERENCES}

Balandreau J, Dommergues $Y$ (1971) Mesure in situ de l'activité nitrogénasique. CR Acad Sci 273, 2 020-2 022

Bhuvaneswari TV, Pueppke SG, Bauer WD (1977) Role of lectins in plant-microorganism interactions. I. Binding of soybean lectin to rhizobia. Plant Physiol 60, 486-491

Bhuvaneswari TV, Turgeon BG , Bauer WD (1980) Early events in the infection of soybean (Glycine max $L$ Merr) by Rhizobium japonicum. Plant Physiol 66, 1 027-1 031 
Bohlool BB, Schmidt EL (1974) Lectins: a possible basis for specificity in the Rhizobium-legume root nodule symbiosis. Science 185, 269-271

Caldwell BE (1966) Inheritance of a strain-specific ineffective nodulation response in soybeans. Crop Sci 6, 427-428

Caldwell BE, Vest G (1968) Nodulation interactions between soybean genotypes and serogroups of Rhizobium japonicum. Crop Sci 8, 680-682

Calvert HE, Pence M, Pierce M, Malik NSA, Bauer WB (1984) Anatomical analysis of the development and distribution of Rhizobium japonicum infections in soybean roots. Can J Bot 62, 2 375-2 384

Cawse PA (1967) The determination of nitrate in soil solutions by ultraviolet spectrophotometry. Analyst 92, 311-315

Dazzo FB, Hubbell DH (1975) Cross-reactive antigens and lectins as determinants of symbiotic specificity in Rhizobium-clover association. App/ Microbiol 30 $1017-1033$

Denison RF, Sinclair TR (1985) Diurnal and seasona variation in dinitrogen fixation (acetylene reduction) rates by field-grown soybeans. Agron J 77, 679-684

Devine TE, Breithaupt BH (1980) Significance of incompatibility reactions of Rhizobium japonicum strains with soybean host genotypes. Crop Sci 20, 269-271

Drevon JJ, Heckmann MO, Soussana JF, Salsac L (1988) Inhibition of nitrogen fixation by nitrate assimilation in legume-Rhizobium symbiosis. Plant Physiol Biochem 26 (2), 197-203

Fehr WE, Caviness CE (1977) Stages of soybean development. lowa State Univ Spec Rep 80, 1

Firmin JL, Wilson KE, Rossen L, Johnston AWB (1986) Flavonoid activation of nodulation genes in Rhizobium reversed by other compounds present in plants. Nature 324, 90-92

Gibson AH, Jordan DC (1983) Ecophysiology of nitrogen-fixing systems. In: Encyclopedia of Plant Physiology (Lange OL, Nobe PS, Osmond CB, Zeigler H, eds) Springer, Heidelberg, vol $12 \mathrm{C}, 301$ 390

Gibson AH, Harper JE (1985) Nitrate effect on nodulation of soybean by Bradyrhizobium japonicum. Crop Sci 25, 497-501

Hardarson G, Zapata F, Danso SKA (1984) Effect of plant genotype and nitrogen fertilizer on symbiotic nitrogen fixation by soybean cultivars. Plant Soil 82 , 397-405

Harper JE, Cooper RL (1971) Nodulation response of soybean (Glycine max (L) Merr) to application rate and placement of combined nitrogen. Crop Sci 11, 438-440

Heron DS, Pueppke SG (1987) Regulation of nodulation in the soybean-Rhizobium symbiosis. Plant Physiol 84, 1 391-1 396

Kvien CS, Ham GE, Lambert JW (1981) Recovery of introduced Rhizobium japonicum strains by soybean genotypes. Agron J 73, 900-905

Malik NSA, Calvert HE, Bauer WD (1987) Nitrate induced regulation of nodule formation in soybean. Plant Physiol 84, 266-271

Mathews A (1987) Host involvement in nodule initiation in the soybean-Bradyrhizobium symbiosis. PhD dissertation, Australian Natl Univ, Canberra, Australia

Nelson DR, Belleville RJ, Porter CA (1984) Role of nitrogen assimilation in seed development of soybean. Plant Physiol 74, 128-133

Obaton M, Sall K, Wery J, Salifou I (1988) Differential effect of drought on nitrate reductase and nitrogenase activities in legumes. 2nd AABNF Meeting, Cairo, Egypt

Pierce M, Bauer WD (1983) A rapid regulatory response governing nodulation in soybean. Plant Physiol 73, 286-290

Pull SP, Pueppke SG, Hymowitz T, Orf JH (1978) Soybean lines lacking the 120000 dalton seed lectin. Science 200, $1277-1279$

Redmond JW, Batley M, Djordjevic MA, Innes RW, Kuempel PL, Rolfe BG (1986) Flavones induce expression of nodulation genes in Rhizobium. Nature 323, 632-635

Ronis DH, Sammons DJ, Kenworthy WJ, Meisinger JJ (1985) Heritability of total and fixed $N$ content of the seed in two soybean populations. Crop Sci 25, 1-4

Schweitzer LE, Harper JE (1980) Effect of light, dark and temperature on root nodule activity (acetylene reduction) of soybeans. Plant Physio/ 65, 51-56

Sinclair TR, Weisz PR (1985) Response to soil temperature of dinitrogen fixation (acetylene reduction) rates by field-grown soybeans. Agron $J$ $77,685-688$

Vest G (1970) Rj3. A gene conditioning ineffective nodulation in soybean. Crop Sci 10, 34-35

Vest G, Caldwell BE (1972) Rj4. A gene condi-tioning ineffective nodulation in soybean. Crop Sci 12, 692693

Weaver RW, Frederick LR (1972) A new technique for most probable number counts of Rhizobia. Plant Soil 36, 219-222 